\title{
The Effects of Currency Crises on Economic Growth: A Dynamic Panel Data Analysis
}

\author{
Arafet Hamida ${ }^{1}$, Tarek Sadraoui ${ }^{2, *}$ \\ ${ }^{1}$ Department of Economics, Higher Institute of Management Gabès, Tunisia \\ ${ }^{2}$ Department of Quantitative Methods, FESM, Tunisia \\ *Corresponding author: tarek.sadraoui@gmail.com
}

\begin{abstract}
The purpose of this research is to study the effect of currency crises on economic growth. To do this, we opted for a dynamic panel data model and impulse response functions for a sample of seventeen emerging countries over a period from 1980 to 2014. The main results of the various empirical investigations show that there is a Negative effect of currency crises on short-term economic growth.
\end{abstract}

Keywords: currency crises, economic growth, impulse response function, dynamic panel

Cite This Article: Arafet Hamida, and Tarek Sadraoui, "The Effects of Currency Crises on Economic Growth: A Dynamic Panel Data Analysis.” International Journal of Econometrics and Financial Management, vol. 6, no. 1 (2018): 1-6. doi: 10.12691/ijefm-6-1-1.

\section{Introduction}

Since the collapse of the Bretton Woods system, the international financial system has experienced many episodes of financial crises. This financial turmoil affected both emerging and developed countries simultaneously. Indeed, an IMF study, covering a period between 1975 and 1997, identified 158 currency crises in developed and emerging countries. Financial crises can manifest as currency crises, banking crises, stock market crises or sovereign debt crises [16]. These various crises, and especially those of foreign exchange, generally provoke a massive outflow of capital and heavy losses in terms of economic growth.

We note that during these last years, the episodes of the crises of exchange of the emerging countries, multiplied. However, the Mexican currency crisis, which began in late 1994 and early 1995, opened a new cycle. Two years later, and exactly in July 1997, the Thai crisis spreading through much of Asia in 1997 and 1998 began, affecting the Philippines, Malaysia and Indonesia. This scourge did not stop there, in August 1998, cames the turn of Russia, which shookes Brazil in late 1998 and early 1999. The following years marked the start of the entry into crisis of the following countries, to namely Turkey, Argentina and Brazil, respectively, during the year 2000, 2001 and 2002.

Exchange rate crises are among the main causes of disruptions in international trade. During these crises, the costs of international settlements can become very expensive or even impossible to honor. Given the severe turbulence related to currency crises. This research work aims to measure the impact of currency crises on the economic growth of emerging countries. First, we present the main works that have dealt with the subject. Then we identify the episodes of crises, then present our econometric methodology that favors a study of impulse response functions and a dynamic panel model so that we can stand out the specific individual and temporal effects of these different economies and the results obtained.

\section{Review of the Empirical Literature}

[4] evaluated the impact of asian crisis on investment and economic growth, adopting a panel data approach on a sample of 67 emerging and developed countries during a period from 1960 to 2000. The author has shown that a currency crisis is associated with a loss of $1.3 \%$ of GDP and $0.4 \%$ investment rate

[5] examined the frequency of financial crises and their effects on economic growth. From a sample comprising between 21 and 56 emerging and industrialized countries, the authors distinguished the periods of 1880-1913 (gold standard period), 1919-1939 (between two wars), 19451971 (the regime of Bretton Woods) and 1973-1997 as post-Bretton Woods period.

The table below shows the average duration and depth of seizures. According to this table, the crises during the Bretton Woods period are characterized by their short duration and not their weak effects on GDP growth compared to other periods.

Table 1. Long-term evolution of duration and depth of crises

\begin{tabular}{|c|c|c|c|c|c|}
\hline & $\begin{array}{c}1980- \\
1913\end{array}$ & $\begin{array}{c}1919- \\
1939\end{array}$ & $\begin{array}{c}1945- \\
1971\end{array}$ & $\begin{array}{c}1971- \\
1997\end{array}$ & $\begin{array}{c}1973- \\
1997\end{array}$ \\
\hline \multicolumn{7}{|c|}{ Average duration of crises (in years) } \\
\hline Currency crises & 2.6 & 1.9 & 1.8 & 1.9 & 2.1 \\
\hline All crises & 2.4 & 2.4 & 1.8 & 2.6 & 2.5 \\
\hline \multicolumn{7}{|c|}{ Average depth (cumulative losses of GDP) } \\
\hline Currency crises & 8.3 & 14.2 & 5.2 & 3.8 & 5.6 \\
\hline All crises & 9.8 & 13.4 & 5.2 & 7.8 & 8.3 \\
\hline
\end{tabular}

Source: bordo and al (2001). 
[5] Bordo et al's analysis revealed several conclusions The crises were followed by economic downturns that lasted 2 to 3 years on average and these crises had an annual cost of 5\% to $10 \%$ of GDP and their effects last on average from 2 to 3 years. The costs of post-1971 crises did not increase compared to the previous period. An important conclusion of this study is that financial globalization has not amplified the severity of crises.

[7] tested the effect of currency crises and political crises on economic growth from a sample of 109 industrialized and emerging countries, using panel data. The authors found that the various shocks are followed by a loss of between $4 \%$ and $16 \%$ of GDP.

[8] tested the relationship between economic growth and exchange rates. The authors have tried to show how exchange rate crises affect economic growth and the trend of GDP, using a sample of 108 emerging and industrialized countries over a period stretching from 1960 to 2006, showing they are associated with a loss of between $2 \%$ and $6 \%$ of GDP. The losses in terms of economic growth appear before the onset of the crisis, which led to the conclusion that the decline in economic activity is one of the precursors of the currency crises. The most interesting conclusion drawn by these authors is that currency crises have a positive effect on economic growth one year after the onset of a crisis.

\section{Identification of Crisis Periods}

The empirical analysis of exchange rate crises assumes that two points are previously specified. First of all the periods of crisis must be identified by the construction of a crisis index. The different theoretical and empirical works show that there is a superiority of one theoretical approach over another, so different sources of tension must be taken into account in order to identify the currency crises of emerging countries.

\subsection{Crisis Index}

Assessing the relevance of vulnerability indicators to a currency crisis require the adoption of an operational definition of the latter, and thus identifying crisis periods throughout the sample. There are different methods for identifying warning indicators empirically, and several definitions of currency crises appear in empirical studies.

Generally, a currency crisis is a situation for which an attack of the currency leads to a depreciation of the same currency. [12] spoke of a currency crisis in the face of a nominal depreciation of the bilateral exchange rate vis-à-vis the US dollar, of at least $25 \%$ in a year. This threshold is conditional on the absence of a crisis during the two previous years. From this criterion a binary index can be constructed: it takes the value 1 in case of crisis in the sense defined above; it takes the value 0 otherwise. [13] defined a currency crisis according to the same criteria.

Simply taking into account the devaluation episodes eliminates the situations in which the speculative attack has occurred but has failed, this is the case where the authorities were able to defend their currencies by an increase in the interest rate or by exhaustion of interest rates foreign exchange reserves. Some authors use a composite index of speculative stress incorporating changes in the exchange rate and reserve losses and / or significant movements in the interest rate.

[9] construct a crisis index equal to the weighted average of changes in nominal exchange rates and changes in foreign exchange reserves. The weights correspond to the inverse of their respective standard deviations, so that both components of the index have identical conditional volatility.

[11] include in their index, other changes in the nominal exchange rate, foreign exchange reserves and changes in the interest rate.

In general, a currency crisis is identified when the crisis index reaches important values. An increase in the crisis index reflects strong pressure on the foreign exchange market resulting in the sale of the national currency. More concretely, a currency crisis is a period during which the index is, generally, two or three times greater than the standard deviation of its average. The crisis index thus makes it possible to empirically identify the vast majority of crises identified in the literature [16,17].

\subsection{Index Calculation}

We have chosen to use a Crisis Index rated CRISE, which incorporates the composition of [7], incorporating observed changes in exchange rates and reserves. This index is defined as the weighted average of changes in the real exchange rate and the official foreign exchange reserves, relative to their respective standard deviations.

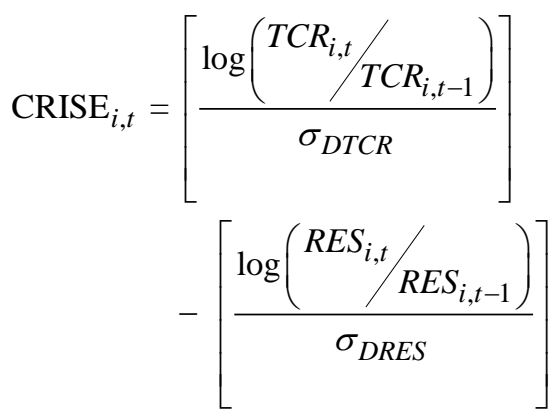

TCR: real exchange rate against the dollar (an increase corresponds to a real depreciation of the domestic currency)

$$
\mathrm{TCR}=\left(\frac{T C N \times I P C^{U S}}{I P C}\right)
$$

TCN: Nominal exchange rate

$I P C^{U S}$ : US price index

IPC: Domestic price index

RES: Foreign exchange reserve in US dollars

DTCR: $\log \left(\mathrm{TCR}_{\mathrm{t}} / \mathrm{TCR}_{\mathrm{t}-1}\right)$

DRES: $\log \left(\mathrm{RES}_{\mathrm{t}} / \mathrm{RES}_{\mathrm{t}-1}\right)$

$\sigma_{\mathrm{DTCR}}$ : Standard deviation of DTCR

$\sigma_{\text {RES }}$ : Standard deviation of DRES

The crisis index (CRISE) is elevated when the standardized rate of real depreciation of the currency is high and / or the standardized rate of the fall in foreign exchange reserves is high. This index therefore makes it possible to identify the periods during which a country is 
subject to a speculative attack, which is then identified by extreme values of the index, more than twice the standard deviation above its average.

The crisis index also makes it possible to define a binary exchange rate index, denoted CC. We consider that there is a currency crisis if this index is greater than its average increased by twice its standard deviation; in this case, the latter takes the value of 1 and 0 otherwise.

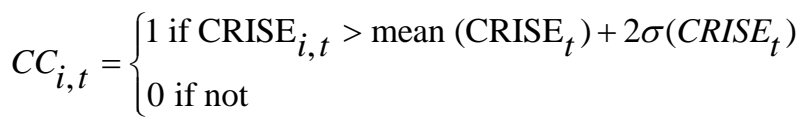

\section{CRISE $_{\mathrm{i}, \mathrm{t}}$ : crise index on $\mathrm{t}$}

\section{$\sigma\left(\right.$ CRISE $\left._{t}\right)$ Standard deviation of crises.}

It should be noted that we tried preliminary tests for the calculation of the crisis index, when the average crisis exceeds three times its standard deviation and when the average crisis exceeds one time its standard deviation, which showed that the choice we made (the crisis index takes the value 1 when the average crisis exceeds twice its standard deviation) is optimal to

Argentina

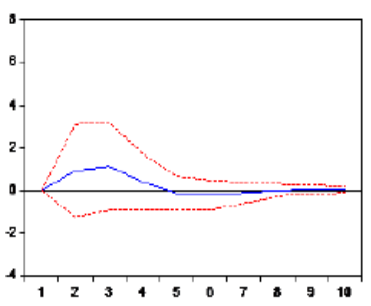

Colombia

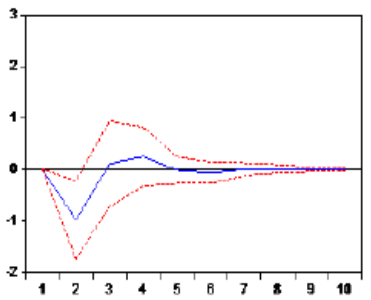

Malysia

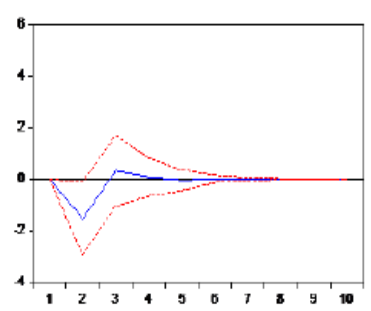

Brazil

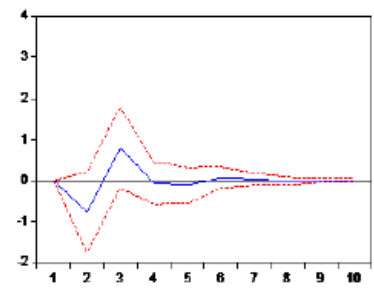

India

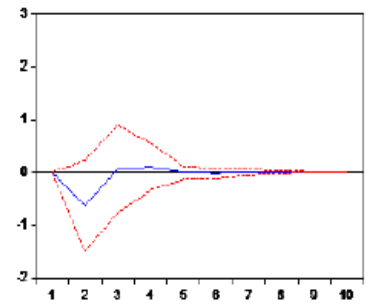

Mexico

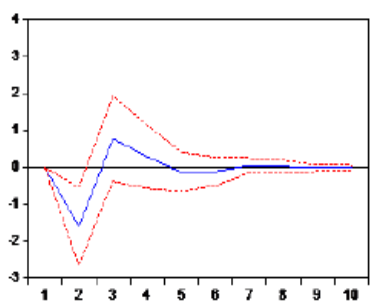

maximize the variability of the crisis index without increasing the errors of type I it is to say, do not predict a crisis that exists.

\section{Impulse Response Function}

In the empirical economic analysis, knowing the impact of the variation of one variable on the other variables is important. This analysis corresponds to the analysis of the impulse responses.

The impulse response functions (impulse response function) make it possible to retrace the dynamics of a variable following a pulse (shock) in another variable of the system. The dynamics of the latter makes it possible to stimulate this response over a longer or shorter period of time. The functions that are most relevant here are those that represent the responses of economic growth to shocks to currency crises. Among the works that have dealt with impulse response functions are [8], who have studied the effects of shocks from currency crises, banking crises and political shocks on economic growth.

Bolivia

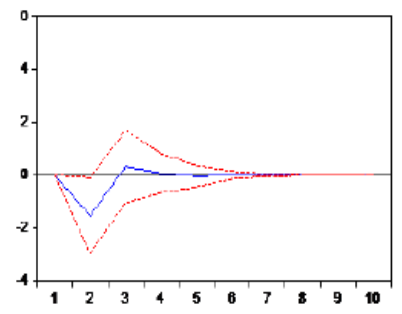

Indonésia

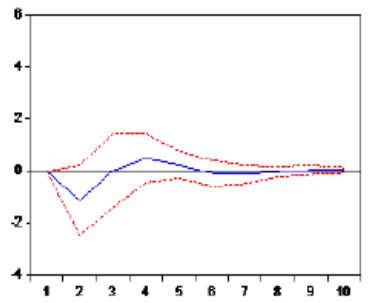

Peru

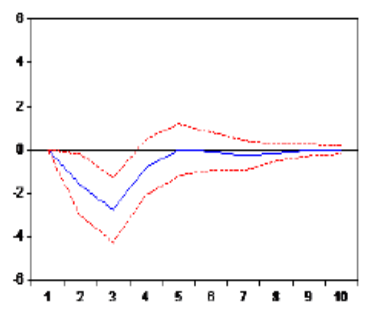

Venezuela

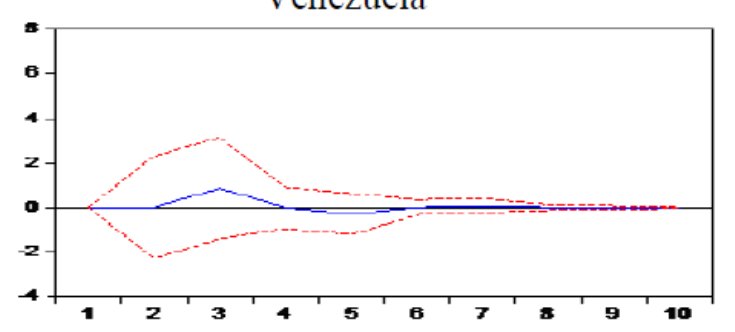

Figure 1. Impulse response functions

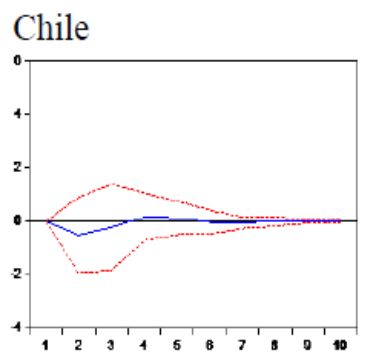

South korea

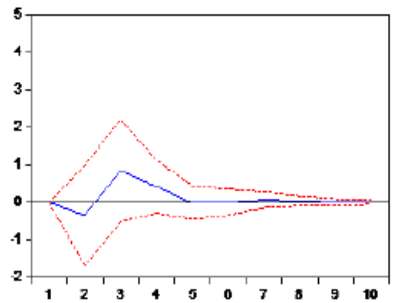

Philippines

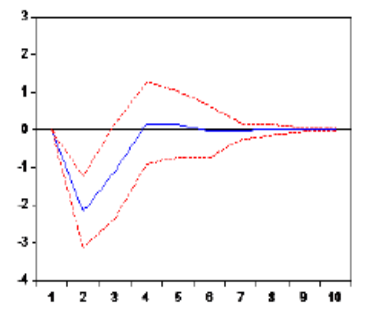


Thus, from a shock (an episode of currency crisis) in a country, the function of impulsional response can determine the amplitude and duration of the response of economic growth. The following charts show the responses of economic growth following currency crises in seventeen emerging countries ${ }^{1}$.

The impact of currency crises on economic growth is negative and persistent over the short term and varies from country to country. For all countries and over a period of 10 years, an exchange rate crisis has had negative effect that can reach $11 \%$ of GDP during the first four years after the crisis. This result shows the deep and persistent effect of currency crises on economic activity. The effect of seizures disappears completely after four years.

For Argentina, a currency crisis over a 10 -year period has a negative effect on economic growth during the first four years. The effect of a crisis can cause a loss of $18 \%$ of GDP. We also note that after four years the effect of the exchange rate crisis on the GDP becomes positive of the order of $4 \%$, a result that is not expected but which is already found by Cerra and Saxena (2008).

The effect of a currency crisis on the Brazilian economy is also negative over the first five years, it is $9 \%$ we also note that the effect of the crisis is persistent since it is from the fifth year that the effect of the crisis on economic growth disappears.

For Thailand, over a period of 10 years, an exchange rate crisis has had negative effect on economic growth during the first two years, which can reach 8\% of GDP. From the third year on, a positive effect of exchange rate crises on economic growth is recorded, which is of the order of $3 \%$ and which continues until the fifth year.

Regarding the case of Turkey, the effect of a currency crisis on economic growth is not stable over time. It is negative the first year of $14 \%$, positive the second of $8 \%$, negative the third of $5 \%$, positive fifth of $5 \%$ to stabilize from sixth grade.

The positive effect of currency crises on economic growth can be explained by the funds mobilized by international organizations such as the IMF to support countries in crisis, and as part of the role allocated to these organizations for the economic stability of countries members. As an indication we recall that the IMF paid during the Mexican crisis is 18 billion dollars which completed a loan of 20 billion US gdollars. The funds mobilized after the Asian crisis exceeded \$ 110 billion. All of these funds, although they have been used in the short term to help countries in crisis stabilize their economies, have played a catalytic role in medium and long-term economic growth.

\section{Dynamic Panel}

Panel data is characterized by dual index data: an individual index and a time index. There is a dependent variable $Y_{i t}$ and explanatory variables $X_{i t}$ for statistical units (individuals, households, firms or countries) indexed by $\mathrm{i}=1, \ldots, \mathrm{N}$ during periods indexed by $\mathrm{t}=1, \ldots, \mathrm{T}$. Panel

\footnotetext{
${ }^{1}$ The countries that make up our sample are: Argentina, Brazil, Bolivia, Chile, Colombia, India, Indonesia, South Korea, Malaysia, Mexico, Peru, Philippines, Singapore, Thailand, Turkey, Uruguay and Venezuela
}

data econometrics make it possible to control the heterogeneity of the observations in their individual dimensions, either by taking into account a specific unobservable effect (random effect) or by taking into account a specific effect that is supposed to be certain (fixed effect).

Panel data has a double advantage over time series and cross sections. This approach makes it possible to simultaneously take into account the heterogeneous nature of individuals and the dynamics of behavior over time. An additional benefit of the panel data is the use of a large sample which should lead to an estimate very close to the true value of the parameters.

The model on panel data is:

$$
y_{i t}=\beta x_{i t}+\varepsilon_{i t}
$$

Panel data provides repeated data for the same individual. By following the principles of the two-factor, individual and temporal variance analysis, we can further decompose the error term and obtain:

$$
\varepsilon_{i t}=\alpha_{i}+v_{t}+u_{i t}
$$

$\alpha_{i}$ Represents an individual effect invariant in time and $v_{t}$ represents a temporal effect. Temporal effects capture aggregated shocks on date (t) and are common to all individuals. Individual effects include all fixed individual variables over time that is not observed.

Two models of individual effects are possible. In the first so-called fixed effect model, it is considered that the individual effects $\alpha_{i}$ are parameters. They are said to be nuisance parameters since they harm the direct estimation of $\beta$. In the second model, these individual effects are random, hence the name random effects model.

To analyze the effect of currency crises on economic growth, we will adopt a methodology based on a dynamic model of panel data. Empirical studies dealing with the subject have shown that the results present two problems: the correlation of specific effects with the term error and endogeneity.

[10] have shown that dynamic panel data specifications and the GMM method provide better results for analyzing the effect of a given policy on economic growth. And this for two reasons, first, the use of panel data allows to highlight specific individual and temporal effects. Then, the endogenous character of some explanatory variables can be taken into account by using the delayed values of these variables as instruments.

\subsection{Statistical Properties}

\section{- Unit root test:}

In order to test the presence of unit root on panel data, we present a summary of the IPS, ADF, LL and PP tests (Philippe Perron) for each model variable

Table 2. Unit root test of growth

\begin{tabular}{|l|c|c|}
\hline Method & Statistic & Prob. $^{* *}$ \\
\hline Levin, Lin \& Chu t* & -8.61527 & 0.0000 \\
\hline Im, Pesaran and Shin W-stat & -9.91368 & 0.0000 \\
\hline ADF - Fisher Chi-square & 166.770 & 0.0000 \\
\hline PP - Fisher Chi-square & 234.475 & 0.0000 \\
\hline
\end{tabular}


Table 3. Unit root test of inflation

\begin{tabular}{|l|c|c|}
\hline Method & Statistic & Prob.** \\
\hline Levin, Lin \& Chu t* & -4.85282 & 0.0000 \\
\hline Im, Pesaran and Shin W-stat & -6.23362 & 0.0000 \\
\hline ADF - Fisher Chi-square & 109.760 & 0.0000 \\
\hline PP - Fisher Chi-square & 179.369 & 0.0000 \\
\hline
\end{tabular}

The results of the stationarity test showed that the variables are stationary, so we can proceed to estimate our model as specified without any modification.

\section{- Descriptive statistics}

The following table presents the descriptive statistics of the different variables used in our sample

Table 4. Descriptive statistics

\begin{tabular}{|l|c|c|c|}
\hline & GDP Growth & INFLATION & CRISE \\
\hline Mean & 4.174528 & 88.35836 & 0.173109 \\
\hline Median & 4.797009 & 8.010168 & 0.000000 \\
\hline Maximum & 18.28661 & 12338.66 & 1.000000 \\
\hline Minimum & -13.12672 & -8.637829 & 0.000000 \\
\hline Std. Dev. & 4.374643 & 623.8840 & 0.378660 \\
\hline Skewness & -0.935489 & 15.01298 & 1.728019 \\
\hline Kurtosis & 4.589870 & 269.3032 & 3.986049 \\
\hline Jarque-Bera & 149.4502 & 1780511. & 320.2212 \\
\hline Probability & 0.000000 & 0.000000 & 0.000000 \\
\hline Sum & 2483.844 & 52573.23 & 103.0000 \\
\hline Sum Sq. Dev. & 11367.67 & $2.31 \mathrm{E}+08$ & 85.16975 \\
\hline Observations & 595 & 595 & 595 \\
\hline
\end{tabular}

\section{- Autocorrelation matrix:}

According to the autocorrelation matrix, the inflation and crisis variables are not correlated and afterwards we can integrate them into the same equation.

\begin{tabular}{|c|c|c|}
\hline & Inflation & Crise \\
\hline Inflation & 1.0000 & \\
\hline crise & 0.1713 & 1.0000 \\
\hline
\end{tabular}

\subsection{Results and Interpretations}

Our objective now is to examine the effect of currency crises on economic growth in a dynamic panel structure (presence of a lagged explained variable among the regressors).

To estimate the impact of currency crises on GDP growth, we use the busiere equation, [17] presented as follows:

$$
P I_{i, t}=\alpha+\beta_{1} G D P_{i, t-1}+\beta_{2} \text { crise }_{i, t}+\beta_{3} \text { iflation }_{i, t}+\varepsilon_{i, t}
$$

In this equation $\alpha$ is a constant, the $\beta_{i}$ are the coefficients to be estimated and $\varepsilon_{i, t}$ is the error term with (i) and (t) index respectively countries and years. The introduction of the inflation variable in the equation to be estimated is for two reasons: first, to account the effect of price change on growth and secondly to ensure that the results are not derived from periods of hyperinflation.
In accordance with the lessons of the theoretical and empirical models, the parameters linked to the increase of inflation and to the existence of a crisis of exchange are of negative expected signs.

The standard estimate of the equation may present various problems. First one could observe heteroscedastic perturbations due to the fact that the countries present specific effects peculiar to each of them and not individual fixed effects. The term of errors would then contain these specific effects, hence the risk of heteroscedasticity. Finally, given the dynamic specification of the model, the "Within" estimator is biase [1,2] because if it is correlated with (the fixed effect), then by definition so it is. In this case the transformation "Within" makes appear (content in) which is incontestably correlated with. As a result, the "Within" estimator is not convergent.

The estimation method used is the generalized method of moments (GMM), which was originally developed by [14] and introduced by [1] in the case of panel data. This is the most widely adopted method of getting around the problems posed by traditional estimators and getting a better estimate. In addition to taking into account the omitted variables and the inverse causality, it also corrects the selection bias. It has the advantage of taking into account the possible endogenousness of the variables by using internal instruments. These instruments in our estimation will be the lagged values of the GDP variable (three delays) and the explanatory variables crisis and inflation.

The results of our estimate of the impact of currency crises on economic growth are shown in the following table:

Table 5. Estimation of the impact of currency crises on economic growth

\begin{tabular}{|c|c|c|c|c|}
\hline Variables & Coefficients & Std. Error & t-Statistic & Prob \\
\hline Constante & 3.182294 & 0.240211 & 13.24789 & 0.0000 \\
\hline PIB (-1) & 0.353552 & 0.037840 & 9.343412 & 0.0000 \\
\hline Inflation & -0.000591 & 0.000260 & -2.267161 & 0.0238 \\
\hline Crise & -2.068730 & 0.454999 & -4.546668 & 0.0000 \\
\hline AR(2) & \multicolumn{5}{|c}{$-1,965(0,0029)$} \\
\hline Chi2(424) & \multicolumn{5}{|c}{$151(1,000)$} \\
\hline
\end{tabular}

The results of our estimation show that the coefficient of the crisis variable is of expected sign and very significant.

The GDP growth rate for the year $(\mathrm{t})$ depends positively and significantly on that of the year $(\mathrm{t}-1)$. The coefficients associated with the delayed growth and inflation variables also have the expected sign and are of the same order of magnitude as those usually obtained in the empirical literature. These results show that the currency crisis variable turns out to be significantly negative. It appears that a currency crisis reduces economic growth by around two percentage points per year and that effect persists for four years. We also note that the tests of Sargan / Hansen and AR (2) confirm the validity of the instruments

\section{Conclusions}

As part of this research work, we sought to determine the effects of currency crises on the economic growth of 
emerging countries. To solve this problem, we first identified the crisis episodes of seventeen emerging countries. The developed model was able to identify all episodes of crisis.

The study of impulse response functions has shown that the impact of currency crises on economic growth is negative and persistent over the short period and varies from one country to another. For all countries and over a period of 10 years, a currency crisis has had a negative effect which can reach 11\% of GDP during the first four years after the crisis. This result shows the deep and persistent effect of currency crises on economic activity.

As for the dynamic panel model we found that currency crises negatively affect economic growth. The coefficients are of expected signs that are consistent with the theories, which consolidate our choice of model and our measure of episodes of currency crisis in different countries of our sample.

\section{References}

[1] Arellano, M. and O. Bond. 1991. "Some Tests of Specification for Panel Data: Monte Carlo Evidence and an Application to Employment Equations," Review of Economic Studies, 58(2), 277-298.

[2] Arellano, M. and O. Bover. 1995. "Another look at the instrumental-variable estimation of error-components models," Journal of Econometrics, 68, 29-52.

[3] Baltagi. B.H, 2005. "Econometric Analysis of Panel Data”. (third ed.) John Wiley \& Sons. PP. 361.

[4] Barro, R. J. 2001. "Economic Growth in East Asia Before and After the Financial Crisis,” NBER Working Papers, 8330.

[5] Bordo, M. D., B. Eichengreen, D. Klingbiel, and M. S. MartinezPeria. 2001. "Is the crisis problem growing more severe?," Economic Policy, 32, 53-82.
[6] Bussière. M , Saxena. S.C and Tovar. C.E 2012, «Chronicle of currency collapses: Re examining the effects on output” Journal of International Money and Finance 31 (2012) 680-708.

[7] Cerra V. et Saxena SC. (2008), 'Growth Dynamics: The Myth of Economic Recovery’. American Economic Review 2008, 98:1, 439-457.

[8] Cerra, V. and S. C. Saxena. 2005. "Eurosclerosis or Financial Collapse: Why Did Swedish Incomes Fall Behind?,” IMF Working Papers, 05/29.

[9] Claessens, S., M. A. Kose, and M. E. Terrones. 2009. "What Happens During Recessions, Crunches and Busts?,” Economic Policy, 24(60), 653-700.

[10] Easterly. W, Loayza. N and Montiel. P "Has Latin America's post-reform growth been disappointing?” Journal of international Economics 1997 vol 43 issue 3-4, P 287-311.

[11] Eichengreen Barry, Andrew K Rose et Charles Wyplosz, 1994 "speculative attacks on pegged exchange rates: an Empirical exploration with special reference to the European monetary system.” NBER working papers nº4898 (October). (Cambridge Massachusetts : National bureau of economic research).

[12] Frankel J. et Rose A. (1996). "Currency Crashes in Emerging Markets: Empirical Indicators” NBER Working paper 5437, January.

[13] Goldfajin I et Valdés R (1998). “Are Currency Crises Predictable?” IMF Working Papers, WP/97/159.

[14] Hansen, L. 1982. "Large sample properties of generalized method of moments estimators," Econometrica, 50(3), 1029-1054.

[15] Janne, O. (2003) "Why do emerging market economies borrow in foreign currency?” IMF Working Papers, WP/03/177.

[16] Kaminsky Garciela, Saul Lizondo, et Carmen Reinhart (1998) "Leading indicators of currency crises " IMF staff papers vol, 45, $\mathrm{N}^{\circ} 1$ (march). International monetary fund.

[17] Cachs. J, Tornell. A and Velasco. A (1995). "The collapse of the Mexican peso: what have we learned?” NBER working papers n5142 (june). 